\title{
自己学習型ニューロ紙幣識別ボードの開発とその汎用展開
}

$\begin{array}{llllll}\text { 正員 } & \text { 竹 } & \text { 田 } & \text { 史 } & \text { 章 } & \text { (高知工科大) } \\ \text { 非会員 } & \text { 西 } & \text { 蔭 } & \text { 紀 } & \text { 洋 } & \text { (グローリー工業) } \\ \text { 非会員 } & \text { 藤 } & \text { 田 } & & \text { 靖 } & \text { (リライアンス }\end{array}$

\section{Development of Self-Learning Neuro-Recognition Board for Banknotes and its Wide Use Expansion}

Fumiaki Takeda, Member (Kochi University of Technology), Toshihiro Nishikage, Non-Member (GLORY LTD.), Yasushi Fujita, Non-Member (Reliance)

Previous work by the authors has proposed a banknote recognition system using a neural network (NN) to develop new types of banking machines such as banknote readers and sorters. Up to now, the feasibility and effectiveness of our research for neuro-recognition system is shown using the large quantity of worldwide banknotes in the commercial market. However, in this neuro-recognition system, we had to transport the banknotes data from the banking machines to a personal computer (PC) in case of learning. After learning on the PC, neural parameters such as weights and masks are downloaded to the neural board. In this way, we have coped with the new banknotes or fluctuation of banknotes in the commercial market. In this paper, we implement the neuro-learning algorithm to this board and extend its specification in order to realize the intelligent machines, which can be tuned by itself according to the banknotes. Furthermore, we newly define specification information, which absorbs difference of some applications, for wide use of this board. Then we advance new neuro-recognition system to palm prints recognition. We construct an experimental system for palm prints recognition using this neuro board, image scanner and PC. Finally, we show the possibility of expansion for this board, concretely.

キーワード：ニューラルネットワーク，紙幣識別，自己学習，仕様書情報，掌紋認識，汎用化

\section{1.はじめに}

これまで著者らは紙慜識別のためにニニーラルネット ワーク（NN）の演算をディジタルシグナルプロセッサ (DSP) で高速に処理するニューロ識別ボード（ボード） の研究と開発を行ってきた(1) (9)。更に，このボードを各 種紙幣処理機に搭載し，海外紙幣が扱える紙幣処理機とし

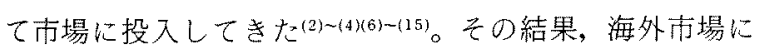
こ机まで以上に迅速にかつ低コストで紙幣処理機を投入す ることが可能となった。しかしながら，これまでのボード は，NNの前向き計算索 DSPで高速に行うものであり， 学習動作である誤差逆伝搬の計算はもっぱら外部コンピュ 一タで行っていだ(5) (12)。すなわち，NNを紙幣の画像情 報とカテゴリ（紙幣の金種，あるい壮金種と紙幣の搬送方 向(1)(2) との一対一の対応付け関数としてボード上で位置 付けていた。また，これまでの識別機開発においては，学 習を実時間あるいはオンラインで行う必要性はなく，十分 な識別性能を発揮するNN ウエイトを作成することが重
要であった(1) (4)。

しかるに，今日，ヨーロッパにおける通貨統合の動きと あいまって貨幣の流通領域が大幅に拡大し上うとしてい る。この貨幣流通の㹡大に伴い, 紙幣の疲弊, 污れ, 破れ などの紙幣状態(1)が大きく変動する可能性がある。この ような事態に対し，非線形識別能力を有する NNをもつ てしても, 開発時のNNウエイト作成に紙幣の状態を学 挤に反映させるだけでは，市場において十分な紙幣識別率 を維持することは難しいと予想される。一般に, 紙幣の位 置ずれおよび回転などの幾何学的举動は，ボード上で補正 可能である(2) (4)(6) (10)。しかるに，紙幣の疲弊，污れ，破 れなどの紙幣状態の劣化メカ二ズムは明確に定式化するこ とが難しく,この限りではない。従って，この対応手段の 一つとして, 変動する学習デー夕を用いて NNウエイト に紙幣の状態を反映させなければならない。

著者らは，上記の今後予想さ机る問題点の一つの解決法 として，これまでのボードにソフトウエアで学習機能を付 加することで, 識別機の市場における識別性能の回復が可 
能であると予想している。つまり, 識別性能を識別機自体 が管理し, 必要に応じて自己学習が可能な自律型のボード が要求されることとなり, 本論文ではこの新しいボードの 提案を行うものである。一方，これまでのボードは紙幣識 別を対象として研究と開発が進められてきた(1) (9)。ここ では, 更にビットマップデータなどの種々の画像データの 扱いを可能とするため新たに仕様書情報を提案し, これに よりボードの入力仕様および機能を掂張する。ここで仕様 書情報とは，個々の制御対象ごとに異なる部分を同一のボ ードで扱う必要性からその異なる部分をパラメータ化し, ウエイトファイルの一部に格納したものである。特に, こ の仕様書情報の提案で従来のラインセンサからのデータだ けでなく，ディジタルカメラやイメージスキャナなどで採 取するデータも処理可能となり, 汎用ボードとして種々の 使用に対応可能としている。

本論文では, 従来のボードにソフトウエアで学習機能を 付加する場合の種々の工夫を識別システムの観点から示 し，その有効性を紙幣および掌紋デー夕を用いた実験シス テムで示す。また，提案するボードを種々の使用に展開可 能とするためシステム内に扔ける仕様書情報の実現方法, ならびに，その具体例をそれぞれ，「紙幣識別」，「掌紋認 識」,「ロボット制御」で示す。

\section{2. 従来のニューロ識別ボードの概要}

ここでは，これまでに著者らが開発してきたボー ド(4) (9) の概要を説明する。従来のボードの概観とその機 能構成を図 1 に示す。従来のボードはDSPを核として構 成され，NN の前向き計算(16)(17)を高速に行うものである。 特に, NNの計算は, 基本的に行列の掛け算として表現 されるので乗算器を有するDSPにとっては都合の良い認 識アルゴリズムである。また，採用したDSP（TMS 320 C 31）は内部デー夕をすべて 4 バイト長で表現し, 更に, 浮動小数型の変数を扱うことが可能である(5) (11)。また， アセンブラと同時にCコンパイラが提供されて抢り，ソ フトウエアの開発を従来の汎用 CPU と同様に容易にして いる(5) (11)。

まず，図1(b)に示すように NNの学習において，紙 幣データあるいはスラブ值(2) (4) がボードからパーソナル コンピュータ (PC) などの外部コンピュータにアップロ ードされる。このアップロードされたデータを用いて, 学 習がオフラインで行わ机る。ただし，ここでスラブ值と は, 紙幣画像をマスクで部分的に被覆し, 被覆されない領 域の画素値の合計値を意味する(2) (4)(18)。著者らは,この マスク処理を NNの前処理に導入し, 紙幣の効率的な特 徵量抽出と NN 構成の小規模化を実現してきた(2) (4)(6) (10)。 次に, 一定量の学習データを用いて学習が十分収束し, 識 別性能の高い NNのウエイトが作成された段階で, この ウエイトはPCからボードにダウンロードされる。また， ボード上では紙幣の識別が実時間で行われる。特に，NN ウエイトは他の NN パラメータと共にボード上のフラッ

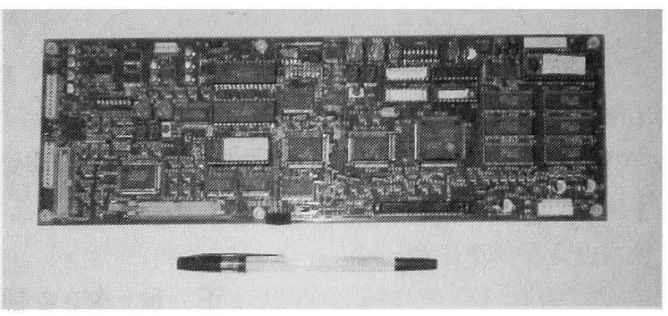

(a) Feature

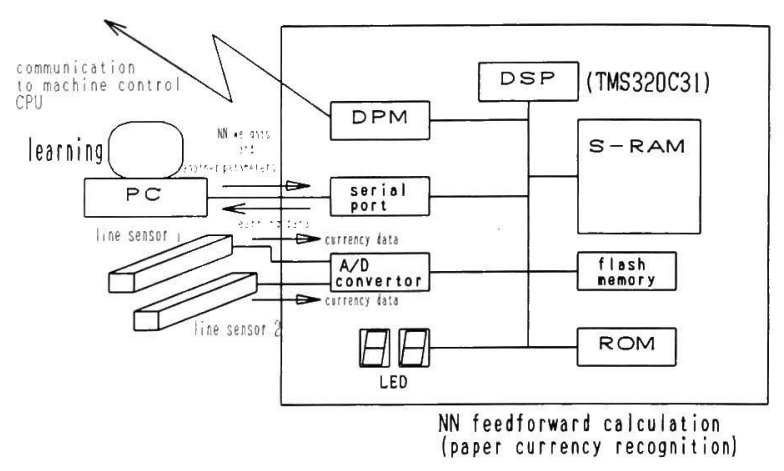

(b) Configuration

図 1 従来のニューロボードの構成

Fig. 1. Configuration of the conventional neuroboard.

シュメモリに格納され，PCで容易に更新でき，紙幣の変 更に迅速かつ柔軟に刘応可能となっている。

\section{3. 自律型ニューロ識別ボードの基本仕様と構成}

ここでは，2.で示した従来のボードの基本仕様を基盤と し，学習アルゴリズムの移植とビットマップデータなどの 汎用画像データの取り込みを可能とする機能を追加し, 基 本仕様を拡張する。特に, 提案ボードが紙幣だけでなく 種々の使用に容易に対応できるようにハードウエアおよび ソフトウエアの構成に種々の工夫を与えている。以下にそ の詳細を項目ごとに示す。提案ボードの概観とその構成を 図 2 に示す。

〈3・1〉自己学習のための課題解決本論文では図 3 に示すように従来の PCなどによる NN の学習をボード 上の EPROMに移植し, ボード単体での学習を実現する ものである。この実現においては, 次の課題を技術的に解 決する必要がある。

（1）紙幣画像などの学習データをDSP のメインメモ リであるSRAM にすべて展開すること

（2）NNの構成および学習パラメータを外部から容 易に更新・閲覧が可能なこと

（3）NNの学習状態を外部コンピュータでモニタで きること

（4） NN の学習結果（ウエイト, 学習定数など）が目 標の収束值に達しない場合でもボード上に残ること

（5）初期学習か継続学習かを容易に外部から指定し， 


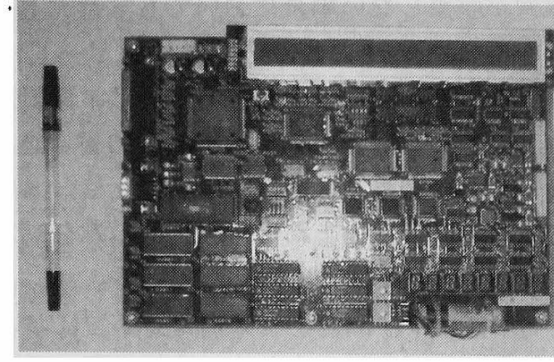

(a) Feature

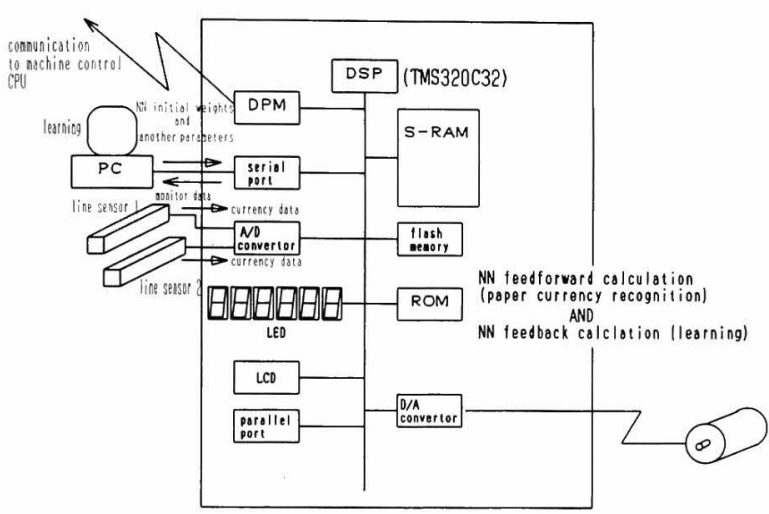

(b) Configuration

図 2 提案するニューロボード

Fig. 2. Configuration of proposed neuro-board.

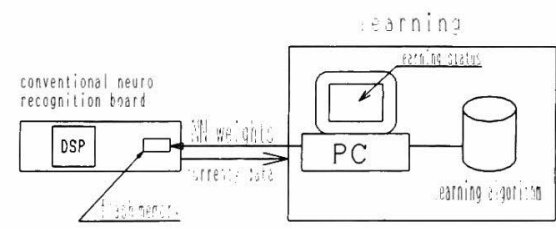

(a) Conventional learning style.

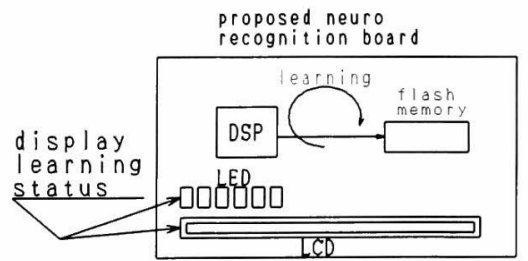

(b) proposed learning style

図 3 種々のニューロボードによる学習方法

Fig. 3. Various learning style using neuro-board.

更に継続学習の場合はボード上の既存ウエイトを使 用可能なこと

これらは，従来の PCによる学習の場合とは異なる新た な仕様の技術課題となる。著者らは上述の個々の課題につ いて以下のような技術的解決策を考案した。

(解決策 1)

一つの制御対象で最大のデータサイズは紙幣などの画像

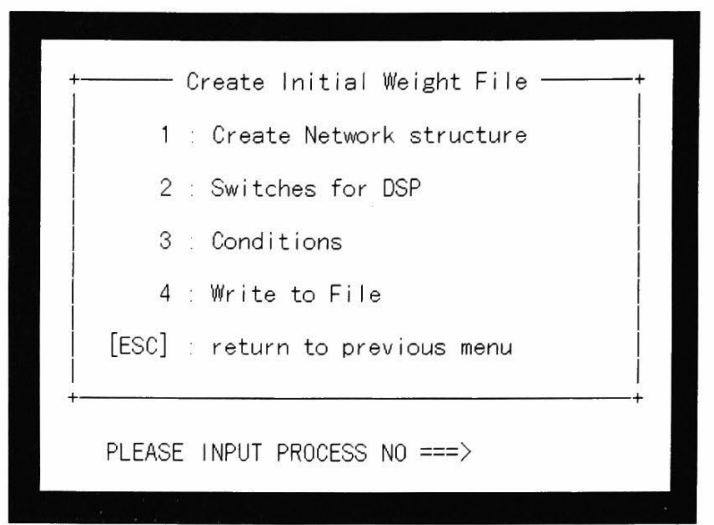

図 4 モニタプログラムの表示例

Fig. 4. Example of display with monitor program.

データであるので，この画像データをマスク処理 し(1) (10)，スラブ值である中間情報にする。例えば，紙幣 データの画像フレームは $216 \times 32 \times 4$ バイトとなるがスラ ブ值は $50 \times 4$ バイトとなり，これをNNの 1 カテゴリに 対する学習データとする。提案システムではメインメモリ (SRAM) の容量 $(64 \mathrm{~K} \times 3 \mathrm{WORD}: 1 \mathrm{WORD}=4$ バイ ト）は限られているので，システムに一つの学習データが 与えられるごとに逐次中間情報に変換し，カテゴリごとの 学習データとしてボード上で編集していく。データ量が所 定の容量（紙幣枚数）に達すれば学習が自動的にボード上 でスタートする。一方，ロボットなどを制御対象とした場 合は，学習を行いながらロボットを動作させ，その動作情 報から新たな学習デー夕を得ることとなる。従って，NN への入力データ量は画像の場合と比較してはるかに少な く，エンコーダなどの情報を中間情報に変換する必要性は ない。この中間情報に“する”/“しない”の違いは以後で 述べる仕様書情報のタスク制御スイッチで制御対象ごとに 設定可能としている。

(解決策 2)

シリアル通信にてボードと PC を通信可能としている。 また，NNの各パラメータを PC 上の初期值作成プログラ ム（モニタプログラムと略記）でメニュー形式で作成する (図 4 参照)。ここで作成されたパラメータをその基本的な 矛盾（パラメータの上下限，関連するパラメー夕の大小関 係など）を自動診断の後に，ボード上のフラッシュメモリ にダウンロードする。また，フラッシュメモリ内のデータ はパラメータごとに管理番号が付与され，PCのディスプ レイ上にパラメータの種類ごとに色分けされて表示され る。更に，アップロードされたパラメータはダウンロード の場合と同じメニュー書式で表示され，パラメータの個々 の修正も対話形式で実現可能とする。その内容も PCのディ スクに格納可能とする。例えば，ウエイトは“71”という 管理番号を持ち，その内容には図 5 に示すようにNNの 構成, 初期学習定数, 収束判定值, 重み係数, 必要とする マスク番号，コメントなどが含まれている。 


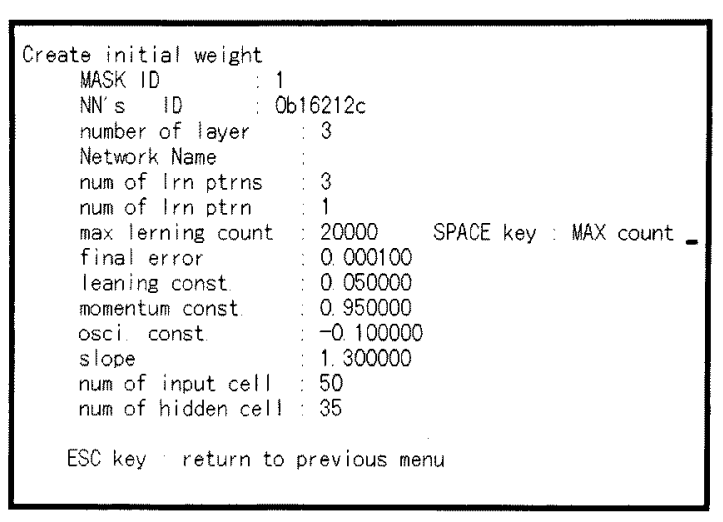

図 5 ウエイトファイルの内容例

Fig. 5. Example of contents for weight file.

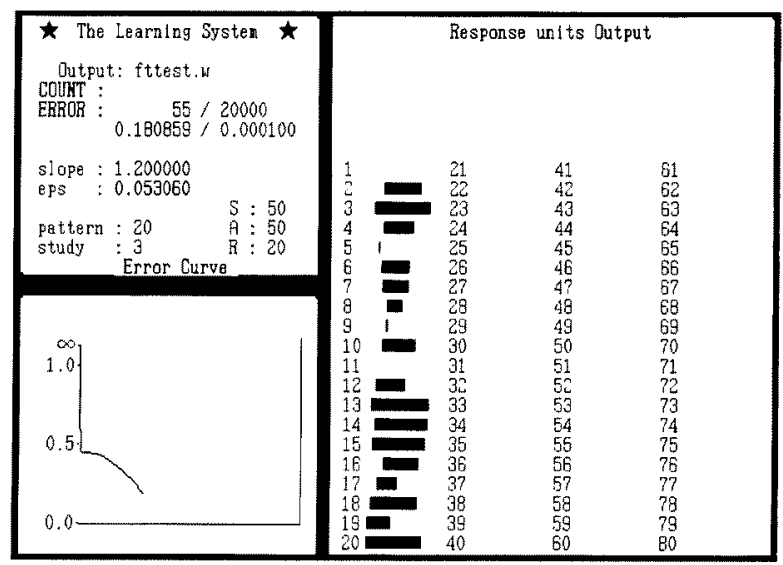

図 6 モニタプログラムによる学習状況の表示例 Fig. 6. Example of display for learning status with monitor program.

\section{(解決策 3)}

ボードと PC との通信プロトルコはコマンドレスポンス 万式を採用する。つまり，PC上でモニタプログラムを動 作させ，モニタプロダラムの命令（コマンド）をDSPが 割り込みとして受け取り，DSPが割り込みを許可した時 点でコマンドに応じたレスポンスをDSP の中間情報とセ ットにしてモニタプログラムに返信する。

例えば，学習状態要求コマンドが PCから発行された場 合, DSP は学習データの提示が一巡したところで割り込 みを許可し，コマンドを受け付ける。次に，DSPはコマ ンドを解析しそのときの学習回数, 学習請差, 学習定数を レスポンスの実態としてPCに通信する。モニタプログラ ムは図 6 に示すようにグラフと折れ線で学習状況を表示す 方。

(解決策 4)

学習が収束しない場合, 学習結果がボード上に残らない 問題点に関し，著者らは次のような工夫を実施している。 つまり，ウエイトのヘッダ部にウエイト書込条件を設定
し，学習が収束しない場合においても学習途上のウエイト をフラッシュメモリに書き込む動作をボードに与えてい る。書込条件としては学習回数あるいは学習誤差がある。 また，ウエイトのフラッシュメモリへの書き込みは最大 3 回実施される。提案システムではフラッシュメモリの管理 において最後に書き込まれたウエイトのみをシステムが再 起動した場合に使用するものとしている。

この仕様により，画像データによる学習においてカテゴ リ間の分離距離が非常に小さく，分離学習が所定の域に達 しない場合，あるいは，ロボット制御のように一定間隔の エンコーダ情報による学習において逐次学習データが変化 し, 収束が不安定な場合においても学習結果はボード上に 残される利点を得ている。

\section{(解決策 5 )}

DSP ボード上にハードウェアスイッチを複数装着し， この組み合わせで継続と初期学習の違いをDSP のブート 時点で判別できる仕様にしている。特に, 前者の場合, フ ラッシュメモリ内の最後に書き込まれたウエイトを初期值 としている。また, 従来の学習のように PCで作成された ウエイトをボードにダウンロードし，これを初期値にして 継続学習を実施することも可能としている。更に，DSP で乱数にて発生した初期值を使用する仕梯も組み入れてい る。

〈3・2〉 ハードウェア構成ボード単体で学習動作を 可能とし，更に，認識および制御などの各種使用に対応す るために，新たに，モード設定スイッチ，LED，液晶表 示板 (LCD), D/A 変換器, パラレル通信ポート, ゙ュア ルポートメモリ (DPM) への延長ポートなどを追加する。 また, 従来と同様に, A/D 変換器抢よびシリアル通信ポ 一トも実装する。LED および LCD には学習状沉, 動作 モード, 識別結果, 更に, エラーなどが表示される。ま た, D/A 変換器はボードから得られる制御信号で直接モ ーターなどのアクチュエータ類を駆動する場合に使用され る。DPM は本来, 上位のメカ二ズム制御用 $\mathrm{CPU}$ との通 信に使用される。更に, DPMへの延長ポートは, PCの 内部バスと専用ケーブルで接続することにより，イメージ スキャナやディジタルカメラなどで得られるデータを PC を媒介にしてボードでアクセス可能としている。

〈3・3〉学習アルゴリズムの移植ここでは, ボード への学習アルゴリズムの移植，NNの構造およびパラメ 一夕決定, 更に, 学習の収束判断について述べる。

「アルゴリズムの移植」

従来ボードと同様にNNの構成は階層型の 3 層構造と する。これを(1)式の改良型の BP 法(1) (4)で学習させ, ウエイトおよび最終的な学習定数を得る。

$$
\begin{aligned}
\Delta W_{i, j}(t)= & -\varepsilon d_{j} \cdot o_{i}+\alpha \Delta W_{i, j}(t-1) \\
& +\beta \Delta W_{i, j}(t-2) \cdots \cdots \cdots \ldots .
\end{aligned}
$$

ここで, $\Delta W$ はウエイトの修正量, $\varepsilon, \alpha, \beta$ は定数, $d$ は一般化誤差，oは出力をそれぞれ示す。図3(a)に示す ように，従来はこれに紙幣データ，あるいは，スラブ值 
(マスク処理後の值) を与えて紙幣識別の学習を $\mathrm{PC}$ 上で 行っていた(5)-(12)。ここでは，Cで記述されたBP法のプ ログラムをDSPのCコンパイラでコンパイルし，ボード への学習アルゴリズムの移植を実現している。学習形態は 図 3(b)に示すようにボードでの単体動作となる。

一方，紙幣を制御対象とする場合は，紙幣 1 枚ごとにマ スク処理を実行し, 中間情報にしてSRAM の容量に取め ている。また，BP法のプログラム自体も EPROM から SRAM に展開している。更に, フラッシュメモリのNN の構造, 学習定数, 初期ウエイト, マスク情報, ほかのパ ラメータもすべて SRAMに展開し, 処理の高速化を図っ ている。NNのフィードフォワード処理は従来のボード と同様のプログラムを使用している。これはニューロ演 算部分をDSP のアセンブラで記述し, リアルタイムプロ グラムとして DSPの乗算器を直接駆動するなどの最適化 を図ったものである(5)(11)。本来は学習プログラムの>ィー ドフォワード処理もこのプログラムを使用すべきである が，本論文では学習アルゴリズムの移植に重点を置き，こ の部分の最適化は実施していない。

\section{$\lceil\mathrm{NN}$ の構造決定」}

ボード上での NN の構造決定は次のように実施してい る。つまり，NNの構造パラメータを PC 上でモニタプロ グラムを使用してメニュー形式で作成する。初期值はモニ タプログラムが読み込むパラメータファイル内に記述さ れ，モニタプログラム起動時にディスプレイに表示され る。次に, 会話形式でパラメータの変更をメニュー上で害 施する。基本的なパラメー夕入力の醀認を害施後に，关の 内容はウエイトファイルに格納され，モニタプログラムに よりシリアル通信を介してDSP ボードのフラッシュメモ リにダウンロードされる。DSPは起動した時点でフラッ シュメモリの内容を読み取り，指定された NNの構造が SRAM に展開されることとなる。

更に，NNの入力変数の設定においては以下の手続き で実施するものとしている。まず, NNの入力変数とし ては, 学習定数 ( $\varepsilon, \alpha, \beta:(1)$ 式参照), 可変温度勾配 $T$, 学習回数, 収束判定值, 学習データ数などがある。こ れはNNの固有情報としてウエイトファイルに格納され， $\mathrm{NN}$ の構造と同様に PC からフラッシュメモリにダウンロ ードされる。また，これ以外に入力画像のどの領域を認識 処理に使用するかという情報を格納したマスクファイル， ならびに，ライセンサなどのキャリブレーション情報を格 納したセンサデータファイルもウエイトファイルと同様に モニタプログラムでフラッシュメモリにダウンロードされ

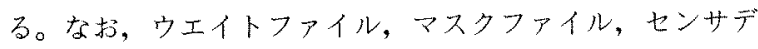
ータファイルはすべてダウンロードと同じ書式でDSP ボ ードから PCへモニタプログラム老用いてアップロードで き, 内容の随時更新を可能とし, 汎用性を高めている。

「学習の収束判断」

本論文での開発に扔いては，ボードでの過剩学習に対す る直接的な対策は施していない。これまでの PCでの学習
に関する収束判定値，ならびに，学習回数，更に，学習デ 一夕量は十分信頼性の高い認識のウエイトを実験的に発生 していると思われる(1)〜10)。ただし，著者らは学習がゆる やかな勾配で収束カーブを描いて収束判定值に達した場合 （図7(a)参照）のみを大域解に達したものと判断し，そ のときのウエイトを種々の識別機に摘要してきた(1) (10)。

一方，学習が急激な勾配で収束判定值に達した場合（図 7(b)参照) は, 局所解に宿ったと判断し, 初期値および 学習データの見直しを実施してきた。従って，ボードでの 学習に扔いても PC 上でモニタプログラムを動作させ，学 習の収束状況を収束力ーブで見極めることによりある程度 適切な学習がボード上で実施されたか否かの判断は可能で あるとしている。

〈3・4〉ソフトウエア構成＼cjkstart困 8 のソフトウエア構成 に示すように，ボードの動作モードは，従来，識別および PCとの通信であったが(5) (11)，提案するるボードでは新た に学習モードを追加する。特に学習においては、二種類の NNウエイトの作成方法が考えられ，それぞれ，オンラ イン学習とオフライン学習と記述する。

以下に各種モードについて説明する。

(i) 通信モード

PCとボードとのシリアル通信を行う。これにより， NN ウエイト抢よびそのほかのパラメータのPCとのダウ ンロード抢よびアップロードが可能となる(5) (11)。

(ii) 識別モード

従来のボードと同様に，既存のNNウエイトによる NN O前向き計算を行う(5) (11)。

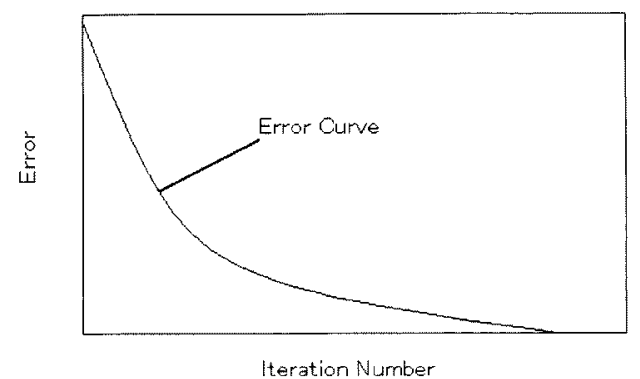

(a) Convergence with gloval minimum.

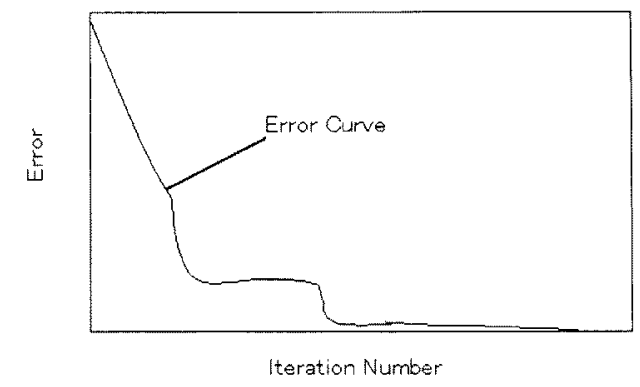

(b) Convergence with loacl minimum.

図 7 学習の収束形態

Fig. 7. Varity of convergence for NN learning. 


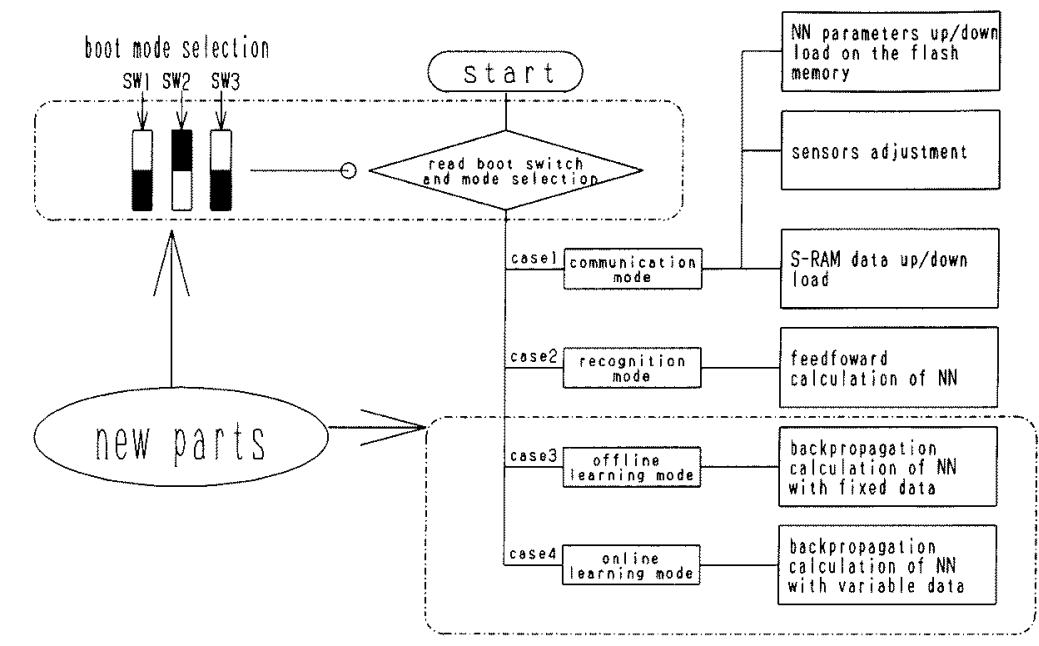

図 8 提案するニューロボードのソフトウエア構成

Fig. 8. Software configuration of the proposed neuro-board.

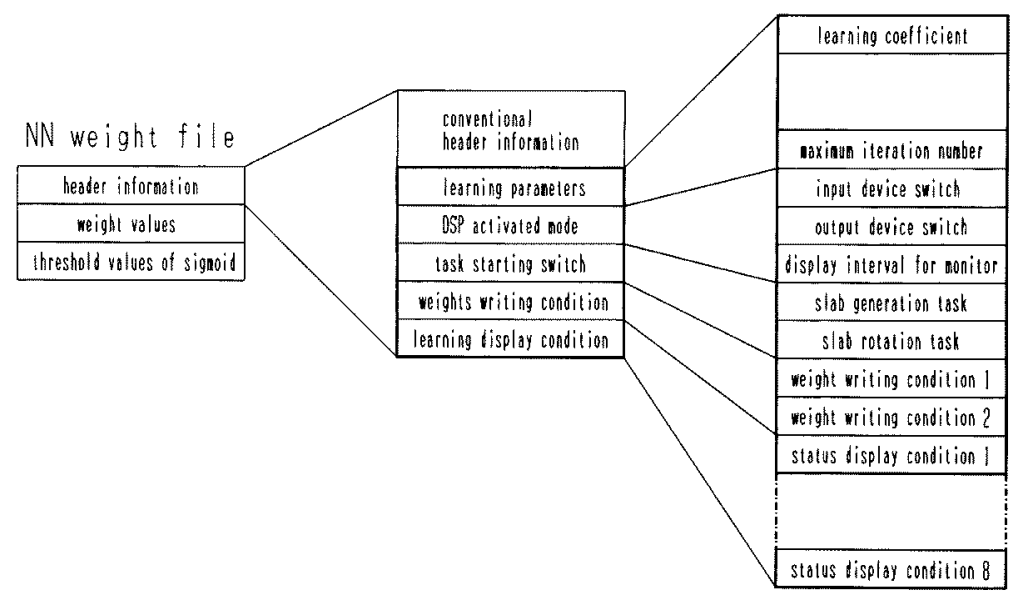

図 9 NNウエイトと仕様書情報

Fig. 9. NN weights and specification information.

(iii）オンライン学漗モード

識別機などの制御対象を動作させながら学習を実行す る。すなわち，学習途上のウエイトで制御対象に入力を与 え，制御对象から動作情報を得る。この情報を新たな NNの学習データとして用いる学習方式である。

(iv) オフライン学㖬モード

従来のPCによる学習動作をボード上で行う。つまり， 固定した学習データで学習が行われる。

特に(iii)と（iv）の違いは,（iii）が学習過程で学習データ が変罡されるのに対し，(iv)では学習が完了するまでは学 習デー夕牥交更さ机ないという点である。

〈3.5〉仕様書情報次に, 提案するボードを各種使 用に柔軟に対応させるために，本論文では仕様㫪情報を提 案している。この倠様書情報とは, 個々の制御対象ごとに 異なる部分を 1 種類のボードで扱う必要性からその異なる
部分をパラメータ化し，ウエイトファイルの一部に格納し たものである。例えば，紙幣識別装置はアナログ入力ポー トを使用している。これに対し, 掌紋認識装置はスキャナ からシリアルポートを介し、データを得る。この違いを仕 様上の違いとし，仕様書情報を含めている。これにより， ボードの汎用性を大幅に高めることとなる。また，この仕 様書情報は初期ウエイトのヘッダ部分に付加され，PCか らボードにダウンロードできるものとしている。その具体 的な内容は図 9 に示すように, 制御対象のボードに対する 入力および出力形態，また，処理するデータタイプ，更 に，システム中のどのタスクを起動するかなどを定義して いる。また，この情報自体は PC 側で作成でき, 最初はデ フォルト值をメニュー上に表示し，制御対象ごとにそのデ フォルト值を会話形式で変更できるようにしている。その 制御対象ごとの具体例冢图 10 に示す。（a)ラインセンサ 


\begin{tabular}{|l|l|l|l|}
\hline Specification \\
information
\end{tabular}

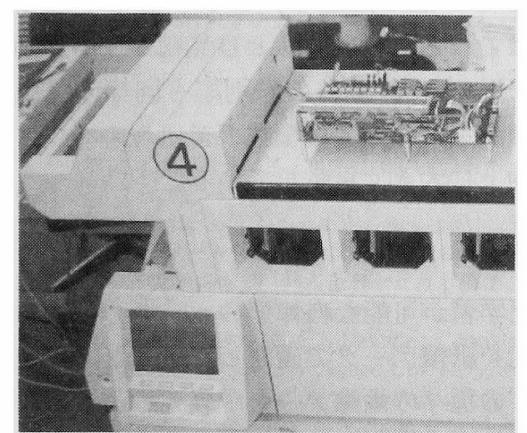

( a )

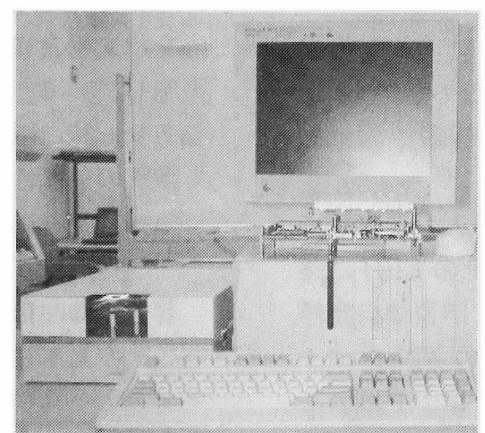

(b)

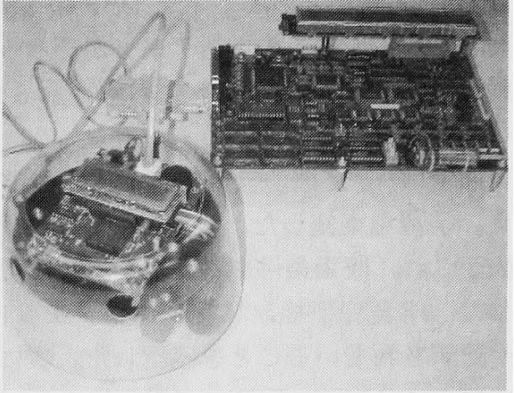

(c)

図 10 種々のアプリケーションに対する仕様書情報の具体例

Fig. 10. Examples of specification information for various applications.

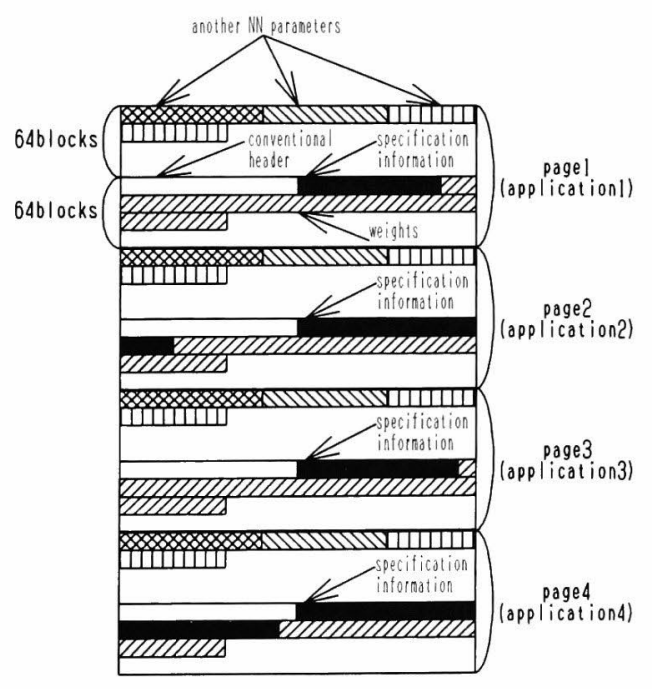

図 11 仕様書情報のメモリ構成

Fig. 11. Memory mapping of the specification information.

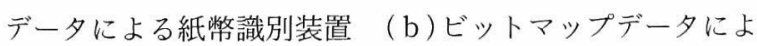
る掌紋認識装置 ( c ) 自走型ロボットの場合をそれぞれ示 す。また，この情報はボード上でフラッシュメモリに格納 される(5)(11)。そのメモり構成は図 11 に示すように, 128
ブロック（1ブロック $=1,024$ バイト）を 1 ページとして 扱い, 1 ページで一つの制御対象の情報を格納するものと する。

特に, 1 ページ内の上位 64 ブロックには, NN ウエイ 卜以外の NN パラメータが格納される。また, 下位 64 ブ ロックの先頭から NNウエイトが格納される。学習動作 において，NNウエイト部分は学習状況に応じて更新さ れ，学習が収束判定值に達した場合のみ，1ページの後半 部分をすべて消去し, 判定值に達したときのウエイトだけ を書き込む。DSP ボードが再起動した場合は，このウエ イトのみを使用することとなる。

\section{4. ニューロ識別ボード上での学習実験}

ここでは, 提案するボード上での学習実験を二つの場合 について行う。一つは，これまで著者らが行ってきた紙幣 識別の学習である。また，もう一つは汎用画像データとし てビットマップ形式で表現された掌紋画像を用いた認識学 習である。ただし, どちらもオフライン学習とする。以下 にそれぞれについてボードの機能とシステム構成について 述べる。

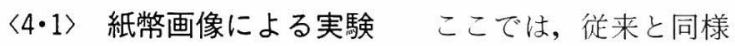
な紙幣画像を用いて実験を行う。紙幣識別機からのセンサ データ (アナログ信号) が, ボード上の $\mathrm{A} / \mathrm{D}$ 変換機を通 


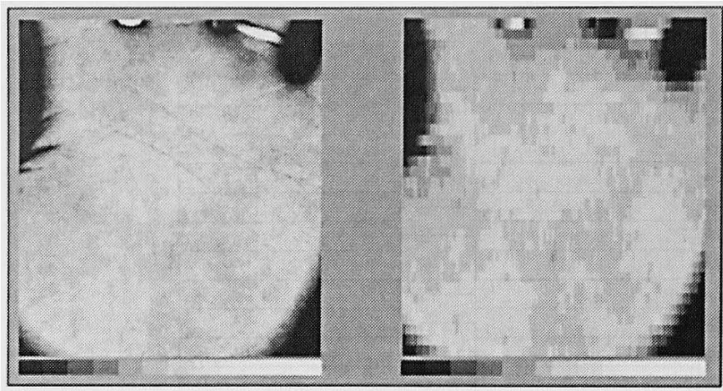

(a) Original figure.

(b) Converted figure

図 12 掌紋画像

Fig. 12. Figures of palm print.

してDSPに与えられる。次にDSP の SRAM 上に学習に 必要とされるすべての学習データがそろった段階で学習が 起動される。初期ウエイトに内蔵される仕様書情報は図 10 (a)で示したものとなる。

実験では，3 金種の紙幣を各 2 枚ずつ学習データとして 与え, 学習を実施した。学習状況はボード上の LED に逐 次表示され, 収束条件を満たしたところで, 学習は自動停 止した。学習完了後, フラッシュメモリ内の NN ウエイ トが更新されていることを確認した。次に, ボード上のモ ード設定スイッチで識別モードに設定し，ボードを再起動 した。これにより，学習した紙幣と同種類の紙幣を実験機 に投入し，正しい識別結果が LED 上に表示されることを 確認した。この場合, 未学習デー夕を各金種ごとに 20 枚 識別し，97\%の識別率を得た。

〈4・2〉掌紋画像による実験続いて, 掌紋画像を用 いた実験を実施する。図 12 ( a )にイメージスキャナで採 取した採取画像（75 dpi）と図（b）にNNに入力するため に PC 上で変換した画像を示す。特に，ここでの変換とは 採取画像の 9 画素加算平均を意味する。また，初期ウエイ 卜に内蔵される仕様書情報は図 10 ( b ) で示したものとな る。実験システムでは, イメージスキャナと PCを SISC ケーブルで接続し, PC とボードはシリアルケーブルで接 続する。この実験システムでは, 紙幣識別の実験システム の構成とは異なり, PCがボードに対してマスタとしての 位置付けとなる。一方, ボードはスレーブとして位置付け され, $\mathrm{PC}$ からのコマンドを受け, 要求されるレスポンス をPCへ返すものとする。学習および認識はすべて PC 側 からのコマンドで起動する。学習モードのレスポンスの内 容は, 学習回数, 学習誤差, NNの出力ユニット值であ る。また, 認識モードのレスポンスの内容は, 認識したパ ターンと NN の出力ユニット值である。特に, 紙幣識別 の場合では, ボードが単独で起動するのに対し, 掌紋認識 の場合では PC からのコマンドで起動する。

実験では, 3 人分の掌紋を, それぞれ, 2 回スキャナで 採取し, 学習データとしてボードに与えた。これにより, 掌紋データによる学習を実施した。学習状況は, PCの要 求に従いボードからのレスポンスとして PCが受け取り,
モニタに表示された。また, 紙幣と同様に LEDにも表示 された。学習が収束条件を満たして自動停止し, フラッシ コメモリ内の NN ウエイトが更新されていることが確認 できた。更に, 認識モードでボードを再起動し, 新たに採 取した掌紋を評価した場合, 正しい認識結果が LED とモ ニタに表示された。この場合, 新たに 3 人の掌紋を 5 回認 識し, $90 \%$ の認識率を得た。

$$
\begin{aligned}
& \text { ここで認識率は ( } 2 \text { ) 式(1) (4) で示される。 } \\
& \text { 認識率=(正しく認識された個数一不十分な NN の反 } \\
& \text { 応を示した個数)/(認識評価されたすべての } \\
& \text { 個数) } \times 100(\%)
\end{aligned}
$$

特に, 分子は NNの反応が正しいパターンであっても NNの反応值をしきい值で確認し，しきい值を下回る反 応を示す場合にはこれを正しい認識とは見なさない評価を 実施している(6) (10)。また, 紙幣の識別率も同様の算出式 であり，特に紙幣識別においては複数の後処理の一つとし て識別の信頼性向上に大きく貢献している。

\section{5.おわりに}

著者らは, 自己学習が可能な自律型のボードの提案を行 い, その基本性能を紙幣データで確認した。また，ビット マップデータなどの種々の画像データが扱えるようにニュ 一ロボードの入力仕様を拡張し, 従来のラインセンサから のデータだけでなく，ディジタルカメラやイメージスキャ ナなどで採取するデータも処理可能となることを実験的に 確認した。更に, 種々のアプリケーションにボードを適用 可能とするために，仕様書情報を新たに NN ウエイトに 追加し, ボードの汎用性を高めた。

今後, 市場において自己学習機能は紙幣処理機の高い識 別性能の維持に大いに貢献するものと予想される。

(平成 11 年 8 月 15 日受付, 同 12 年 7 月 21 日再受付)

\section{文献}

（1）竹田史章・大松 繁・井上 卓・尾波宰三：「ニューラルネット ワークを用いた高速搬送紙幣の識別」, 電学論(C)，112, No.4 $249 \sim 258$ (平 4)

(2) F. Takeda and S. Omatu: "Recognition System of US Dollars Using a Neural Network with Random Masks", Proceeding of the International Joint Conference on Neural Networks, Nagoya, Japan, 2, 2033-2036 (1993)

(3) F. Takeda, S. Omatu, S. Onami, T. Kadono, and K. Terada: "A Paper Currency Recognition Method by a Small Size Neural Network with Optimized Masks by GA", Proceedings of IEEE World Congress on Computational Intelligence, Orlando, USA, 7, 4243-4246 (1994)

(4) F. Takeda and S. Omatu: "A Neuro-Money Recognition Using Optimized Masks by GA", Advances in Fuzzy Logic. Neural Networks and Genetic Algorithms LNAI 1011 Springer 190-201 (1995)

（5）竹田史章・大松 繁：「ニューロ紙幣識別ボードの開発」，電学論 (C), 116, No. 3, 336 340 (平 8)

(6) F. Takeda and S. Omatu: "A Neuro-System Technology for Bank Note Recognition", Proceedings of Japan/USA symposium on Flexible Automation, Boston, USA, 2, 1511-1516 (1996)

( 7 ) F. Takeda and S. Omatu: "A Neruo-Recognition Technology for paper Currency Using Optimized Masks by GA and Its 
Hardware", Proceedings of International Conference on Infor mation Systems Analysis and Syn-thesis, Orlando, USA, 147 152 (1996)

(8) F. Takeda, S. Omatu, and T. Nishikage: "Neural Network Recognition System Tuned by GA and Design of Its Hardware by DSP", Proceedings of International Symposium on Artificial Intelligence in Real-Time Control, Malaysia, 356 361 (1997)

（9）竹田史章・大松 繁・寺田兼吾：「遗伝的アルゴリズムとDSP による紙幣識別用ニューロシステム技術とその応用」，機械学論 誌 (C), 63, No. 615, 3933 3940 (平 9)

(10) F. Takeda and S. Omatu: "Neural Network Systems Tech nique and Applications In paper Currency Reccognition", Neural Network Syst., Techniq. and Appl. ACADEMIC Press 5. Chapter 4, 133 160 (1998)

(11) F. Takeda, S. Omatu. and Y. Matsumoto: "Development of High Speed Neuro-Recognition Board and Application for Paper Currency", The International Wompshop on Signal Processing Application and Technology, 49〜56 (1998)

(12）竹田史章：「GAによりチューニングされたニューロ識別システ ムとその海外紙幣への応用」, 電学論 (C), 118, No. 5, 101〜108 (平 10)

（13）竹田史章・田中雅博・西蔭紀洋・藤田 靖：「ニューロ多国籍紙 幣識別におけるガウス密度関数による目的外紙幣の排除法」, 電 学論 D, 118, No. 12, 1361 1369 (平 10)

(14) F. Takeda, Nishikage, and Y. Matsumoto: "Characteristic Extraction of Paper Currency using Symmetrical Masks Optimized by GA and Neuro-Recognition of Multi-National Paper Currency", Proceedings of IEEE World Congress on Computational Intelligence. Alasa, USA, 1, 634 639 (1998)

(15) T. Nishikage and F. Takeda: "Axis-Symmetrical Masks Optimized by GA for Neuro-Currency Recognition and their Statistical Analysis", Proceedings of World Mulli-Conf. Syst. Cybernetics, Informatics, Orlando, USA, 2, 308 314 (1998)

（16）麻生英樹：ニューラルネットワーク情報処理, pp. 39〜54 (平元) 産業図書

（17）菊地豊彦：入門ニューロコンピュータ, pp. 35〜67 (平 2) オーム 社

(18) B. Widrow, R. G. Winter, and R. A. Baxter: "Layered Neura Nets for Pattern Recognition", IEEE Transaction Acoustic, Speech \& Signal Processing, 36, No. 7, 1109 1118 (1988)

竹田史章（正員） 1958 年 4 月 27 日生。 84 年 3 月名古屋

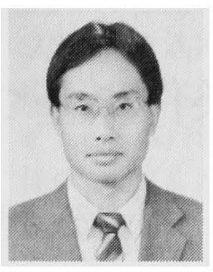
工業大学大学院工学研究科修士課程修了。同年 4 月豊田中央研究所入社。 86 年 9 月ク゚ローリー 工業(株)入社。紙幣識別に関する研究開発に従 事。94 年 3 月徳島大学大学院工学研究科博士後 期課程修了。工学博士。99 年 4 月より高知工科 大情報システム工学科教授。9 5 年日本機械学会 関西支部賞(研究賞)，95 年計測自動制御学会 論文賞, 96 年高度自動化技術振興財闷研究業績表彰 (本賞)，96 年 市村学術賞 (功績賞) 受賞。システム制御情報学会, 日本機械学会, 計測自動制御学会会員。

西 唡 紀 洋 (非会員) 1969 年 1 月 2 日生。 95 年 3 月電気通

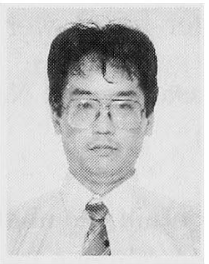
信大学大学院電気通信学研究科博士前期課程修 了。同年 4 月グローリー工業(株) 入社。紙幣識 別に関する研究開発に従事。電子情報通信学会 会員。

藤 田

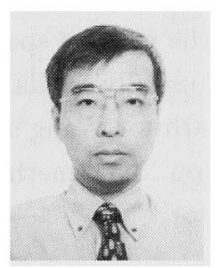

清（非会員） 1955 年 3 月 30 日生。97年 3 月早稲 田大学大学院工学科修士課程修了。同年富士通 (株) 入社。同年富士ファコム制御(株)に出向。 振動, 騒音解析パッケージの開発に従事。89 年 (株)リライアンスに入社。紙幣識別, 画像処理 システムの開発などに從事。電子情報通信学会, 自動車技術会会員。 